\title{
Uji Model Kualitas Audit: Studi Empiris Perusahaan yang Melakukan IPO di Bursa Efek Indonesia
}

\author{
T. Husain ${ }^{*}$, Melani Quintania ${ }^{* *}$, Nedi Hendri ${ }^{* * *}$ \\ *)Universitas Persada Indonesia Y.A.I, Jakarta Pusat,Indonesia, thusain050686@gmail.com \\ **)Universitas Darma Persada, Jakarta Timur, Indonesia,melani_quintania@fe.unsada.ac.id \\ **)Universitas Muhammadiyah Metro, Kota Metro, Indonesia,nedi_hendri@yahoo.com
}

ARTICLE INFO

Article history:

Received 8 Juli 2020

Received in Revised 10 Oktober 2020

Accepted 28 November 2020

Keywords:

Audit quality, IPO, price-to

book value
ABSTRACT
Various financial statement scandals lead to a low public perception of audit quality. The quality of the audit itself can be studied from various perspectives. This research uses the paradigm of thinking to test the modeling of audit quality in predicting financial ratios consisting of liquidity ratios, activity ratios, solvency ratios, profitability ratios and market prospect ratios. The type of research is causality with a quantitative approach. The subject of this research uses a public company that do Initial Public Offerings (IPO) in 2019. Data analysis methods uses logistic regression analysis. The findings of this study show that meets the specifications of the model, with nagelkerke $r$ square score of 0.151 which means it has a weak influence in explaining the model. Besides that, does not yield influence simultaneously with omnibus tests of model coefficients and only one proof of the hypothesis of the Financial Ratio's viz price- to book value proxy test that has a partially significant effect with the wald testing.

Berbagai skandal laporan keuangan menyebabkan rendahnya persepsi masyarakat terhadap kualitas audit. Kualitas audit itu sendiri dapat dipelajari dari berbagai sudut pandang. Penelitian ini menggunakan paradigma berpikir untuk menguji pemodelan kualitas audit dalam memprediksi rasio keuangan yang terdiri dari rasio likuiditas, rasio aktivitas, rasio solvabilitas, rasio profitabilitas, dan rasio prospek pasar. Jenis penelitian yang digunakan adalah kausalitas dengan pendekatan kuantitatif. Subjek penelitian ini menggunakan perusahaan terbuka yang melakukan Penawaran Umum Perdana (IPO) pada tahun 2019. Metode analisis data menggunakan analisis regresi logistik. Temuan penelitian ini menunjukkan bahwa model memenuhi spesifikasi, dengan skor nagelkerke $r$ square sebesar 0.151 yang artinya memiliki pengaruh yang lemah dalam menjelaskan model. Selain itu, tidak menghasilkan pengaruh secara simultan dengan uji omnibus koefisien model dan hanya satu bukti hipotesis yaitu uji proksi nilai buku Rasio Keuangan yang memiliki pengaruh signifikan secara parsial dengan pengujian wald.

AKUISISI : Jurnal Akuntansi

Website : http://www.fe.ummetro.ac.id/ejournal/index.php/JA

This is an open access article distributed under the terms of the Creative Commons Attribution 4.0 International License, which permits unrestricted use, distribution, and reproduction in any medium, provided the original work is properly cited.

\footnotetext{
* Corresponding author. Tel.: +0-000-000-0000 ; fax: +0-000-000-0000 E-mail address: thusain050686@gmail.com

Peer review under responsibility of Akuisisi : Accounting Journal. 2477-2984 


\section{PENDAHULUAN}

Berbagai skandal laporan keuangan menimbulkan rendahnya persepsi publik terhadap kualitas audit. Namun, muncul pertanyaan tentang bagaimana mengumpulkan data audit yang melibatkan lebih dari satu auditor. Audit perusahaan global, misalnya, memerlukan partisipasi auditor dari berbagai perusahaan yang mungkin atau tidak menjadi bagian dari jaringan afiliasi. Penyediaan data indeks kualitas audit untuk setiap perusahaan dapat memberikan wawasan jika kualitas audit berbeda secara luas dari perusahaan ke perusahaan (PCAOB, 2015, hal. 26). International Auditing And Assurance Standards Board (IIASB) merekomendasikan kerangka kerja elemen-elemen yang mencakup penilaian kualitas audit antara lain masukan, proses, keluaran, interaksi dari supply chain atas pelaporan keuangan dan faktor kontekstual yang mencakup regulasi dan hukum serta tata kelola perusahaan (IIASB, 2014, hal. 5). Pasar memiliki mekanisme sendiri untuk mengeksekusi segala bentuk tindakan yang tidak sesuai dengan standar yang berlaku, hal ini menjadi penting dalam meningkatkan kesadaran pengguna laporan keuangan seperti regulator, asosiasi profesi, praktisi, investor serta pihak lainnya yang membaca laporan keuangan atas proses audit (DeFond \& Francis, 2005; Ball, 2009). PCAOB semakin memberikan perhatian atas proses audit dalam menjaga kepentingan masyarakat atas pelaporan keuangan yang menjalankan mekanisme pengawasan terhadap proses audit yang dijalankan oleh kantor akuntan publik dalam memastikan laporan audit yang informatif akurat dan independen (Carcello, Hollingsworth, \& Mastrolia, 2011). Keseluruhan dewan standar audit yang merumuskan pengukuran atau indeks kualitas audit tentunya melalui serangkaian tahapan atau proses yang cukup kompleks dengan membandingkan risiko dan penilaian atas kasus-kasus audit yang terjadi selama ini.

Kualitas audit dapat dipelajari dari berbagai sudut pandang, salah satu perspektif yang menjadi kian penting adalah outputnya yaitu laporan audit yang menjadi bagian dari kualitas produk sesuai dengan standar yang ditentukan. Sementara audit juga dianggap sebagai suatu layanan yang harus disediakan oleh auditor yang berkualifikasi dalam proses awal hingga akhir yang tunduk pada kriteria dan standar tertentu (Mashaekhi, Mehrani, Rahmani, \& Madahi, 2013). Dari sudut pandang lain, audit dianggap sebagai layanan yang harus disediakan oleh individu yang berkualifikasi, dan proses pelaksanaannya serta melaporkan hasilnya yang tunduk pada kriteria dan standar tertentu. Jika layanan tersebut disediakan dari pemrosesan awal hingga pemrosesan akhir yaitu berupa laporan audit harus memenuhi standar dan kriteria yang ditentukan maka akan diperlukan kualitas (Ghanbari, Rashidi, \& Abbasi, 2018).

Penelitian terdahulu yang menguji model pengukuran kualitas audit khususnya menggunakan studi empiris pada data bursa, banyaknya pengukuran yang digunakan melatarbelakangi penelitian ini untuk merumuskan dan menguji kecocokan model dalam pengukuran kualitas audit itu sendiri. Subjek penelitian ini menggunakan perusahaan-perusahaan yang listing di Bursa Efek Indonesia yang 
melakukan Initial Public Offerings (IPO), yang mensyaratkan setidaknya Laporan Keuangan Auditan 3 tahun yang menjadi persyaratan pendaftaran kepada Otoritas Jasa Keuangan (OJK) dan permohonan pencatatan saham kepada Bursa Efek Indonesia (BEI) (Indonesia Stock Exchange (IDX), 2015). Penyusunan laporan keuangan secara prospektif dan hal-hal yang mendasari asumsi harus diperiksa dan dilaporkan oleh akuntan yang mengaudit laporan keuangan perusahaan (Otoritas Jasa Keuangan (OJK), 2012) sehingga laporan keuangan perusahaan akan tertuang dan tervalidasi oleh laporan auditor independen yang mencerminkan output dari kualitas audit itu sendiri.

Berdasarkan data BEI mengenai perusahaan yang melakukan IPO di tahun 2017-2019, dapat diketahui bahwa adanya peningkatan sebanyak 18 emiten yang melakukan IPO pada tahun 2018 dan 2019 dibandingkan dengan tahun 2017 yang hanya sebanyak 37 perusahaan. Oleh karena itu, 55 (lima puluh lima) perusahaan pada tahun 2019 ini akan dijadikan subjek penelitian ini untuk diuji berdasarkan pengukuran kualitas auditnya. Pentingnya penelitian ini dilakukan sebagai referensi bagi para peneliti pemula dan kemudahan dalam memilih pengukuran kualitas audit dalam kerangka kerja yang akan diterapkan dalam penelitian-penelitian studi empiris. Penelitian ini merancang model dengan parameter pengukuran mengadopsi pemodelan persamaan struktural untuk diuji kelayakan model untuk menghasilkan kecocokan model yang akan dilanjutkan ke tahap penelitian hipotesis eksperimen.

Model dapat mewakili wawasan baru berdasarkan teori empiris dan dapat dikembangkan yang merepresentasikan sistem dan menggantikan sistem itu sendiri (Holmlund, 2008; Husain T, 2019). Uji model dalam pengukuran kualitas audit terlebih dahulu harus dinyatakan secara eksplitit berdasarkan definisi dari kualitas audit itu sendiri. Di samping itu, definisi kualitas audit diturunkan ke dalam proksi pengukuran berdasarkan formulasi pendekatan yang digunakan. Definisi kualitas audit yang menyatakan bahwa adanya pelanggaran sistem akuntansi dalam perusahaan yang dilaporkan oleh kantor akuntan publik dengan pendekatan proksi Big N (DeAngelo, 1981b; DeFond \& Jiambavlo, 1993). Audit yang berkualitas baik akan dilakukan oleh auditor Big 5 berdasarkan spealisasi industri dibandingkan dengan kategori auditor selain Big 5 (Behn, Choi, \& Kang, 2008).

Berdasarkan tinjauan beberapa literatur, kualitas audit dapat didefinisikan sebagai upaya peningkatan dalam proses audit yang memungkinkan individu atau akuntan publik untuk mendeteksi adanya kesalahan atau salah saji dan hasilnya dituangkan dalam output yang berupa laporan auditor independen. Pengukuran kualitas audit harus dinilai berdasarkan suatu indeks atau pengukuran / pendekatan tertentu yang dirangkum melalui uji empiris dengan dasar temuan penelitian terdahulu (Husain T., 2020). Penelitian ini menggunakan paradigma berpikir untuk menguji model kualitas audit dalam memprediksi rasio keuangan yang terdiri dari rasio likuiditas, rasio aktivitas, rasio solvabilitas, rasio profitabilitas dan rasio prospek pasar. 


\section{METODELOGI}

Jenis penelitian ini adalah riset kausalitas yang bertujuan untuk mencari penjelasan dalam bentuk hubungan sebab-akibat (causal effect) antar beberapa variabel. Penelitian ini merupakan applied research untuk mencari faktor penyebab timbulnya masalah sehingga hasilnya dapat digunakan sebagai dasar pemecahan langkah-langkah perbaikan (Supranto \& Limakrisna, 2019, hal. 3). Penelitian untuk menguji dan membuktikan secara empiris model pengukuran kualitas audit dalam memprediksi rasio keuangan pada perusahaan-perusahaan publik yang melakukan Initial Public Offerings (IPO).

Populasi dalam penelitian ini adalah 55 (lima puluh lima) perusahaan publik yang melakukan Initial Public Offerings (IPO) dengan menggunakan 2 (dua) tahun periode pengamatan yaitu 20182019, dimana keseluruhan populasi akan dijadikan sampel dalam penelitian ini.

\section{Operasionalisasi Variabel}

\begin{tabular}{|c|c|c|c|}
\hline Variabel & Definisi & Proksi Pengukuran & Skema Pengukuran \\
\hline Audit Quality (Y) & $\begin{array}{c}\text { Perusahaan yang } \\
\text { diaudit oleh KAP PwC, } \\
\text { Ernst \& Young, } \\
\text { Deloitte or KPMG } \\
\text { (Big 4) }\end{array}$ & $\begin{array}{l}1=\text { The firm is audited } \\
\text { by a Big } 4 \\
0=\text { The firm is not } \\
\text { audited by a Big } 4\end{array}$ & $\begin{array}{l}\text { Nominal } \\
\text { dummy variable }\end{array}$ \\
\hline \multicolumn{4}{|c|}{$\begin{array}{l}\text { Prior Research: (DeAngelo, 1981b; DeFond \& Jiambavlo, 1993; Behn, Choi, \& Kang, 2008; } \\
\text { Martin, 2013; Wibowo \& Rossieta, 2009; Martin, 2013; Svanström, 2013; DeFond, Erkens, \& } \\
\text { Zhang, 2013; Donovan, Frankel, Lee, Martin, \& Seo, 2014; Qi, Li, \& Tian, 2015) }\end{array}$} \\
\hline Current Ratio (X1) & $\begin{array}{l}\text { Salah satu rasio } \\
\text { likuiditas yang } \\
\text { menggambarkan } \\
\text { kemampuan } \\
\text { perusahaan dalam } \\
\text { membayar kewajiban } \\
\text { yang akan jatuh tempo }\end{array}$ & $\frac{\text { Current Asset }}{\text { Current Liabilities }}$ & Rasio \\
\hline \multicolumn{4}{|c|}{ Sumber: (Subramanyam, 2014, hal. 546) } \\
\hline $\begin{array}{l}\text { Total Asset Turnover } \\
\text { Ratio (X2) }\end{array}$ & $\begin{array}{l}\text { Salah satu rasio } \\
\text { aktivitas yang } \\
\text { digunakan untuk } \\
\text { mengukur seberapa } \\
\text { besar efektivitas } \\
\text { perusahaan dalam } \\
\text { menggunakan sumber }\end{array}$ & $\frac{\text { Net Sales }}{\text { Average Total Asset }}$ & Rasio \\
\hline
\end{tabular}




\begin{tabular}{|c|c|c|c|}
\hline & daya yang berupa aset & & \\
\hline \multicolumn{4}{|c|}{ Sumber: (Brigham \& Houston, 2016, hal. 39) } \\
\hline $\begin{array}{l}\text { Debt-to Equity Ratio } \\
\text { (X3) }\end{array}$ & $\begin{array}{l}\text { jumlah pendanaan } \\
\text { utang dalam struktur } \\
\text { modal suatu } \\
\text { perusahaan }\end{array}$ & $\frac{\text { Total Liabilities }}{\text { Stakeholders'Equity }}$ & Rasio \\
\hline \multicolumn{4}{|c|}{ Sumber: (Subramanyam, 2014, hal. 565) } \\
\hline $\begin{array}{l}\text { Return On Assets } \\
(X 4)\end{array}$ & $\begin{array}{l}\text { Salah satu rasio } \\
\text { profitabilitas yang } \\
\text { digunakan untuk } \\
\text { mengukur kemampuan } \\
\text { perusahaan dalam } \\
\text { menghasilkan } \\
\text { keuntungan dengan } \\
\text { seluruh aset yang } \\
\text { dimilikinya }\end{array}$ & $\frac{\text { Net Income }}{\text { Total Asset }} \times 100 \%$ & Rasio \\
\hline \multicolumn{4}{|c|}{ Sumber: (Titman, Keown, \& Martin, 2013, hal. 11) } \\
\hline $\begin{array}{l}\text { Price-to Book Value } \\
\text { (X5) }\end{array}$ & $\begin{array}{l}\text { Salah satu rasio } \\
\text { prospek pasar yang } \\
\text { digunakan untuk } \\
\text { melihat pengakuan } \\
\text { pasar terhadap nilai } \\
\text { pasar saham satu } \\
\text { perusahaan }\end{array}$ & $\frac{\text { Market Shares }}{\text { Book Value Shares }}$ & Rasio \\
\hline
\end{tabular}

Metode analisis data menggunakan analisis regresi logistik. Penggunaan metode ini cocok digunakan untuk penelitian yang variabel dependennya bersifat kategorikal (nominal atau nonmetrik) dan variabel independennya kombinasi antara metrik dan non-metrik seperti halnya dalam penelitian ini (Ghozali, 2017, hal. 9). Model persamaan regresi logistik adalah:

$$
Y=\beta 1 X 1+\beta 2 X 2+\beta 3 X 3+\beta 4 X 4+\beta 5 X 5+\grave{e}
$$

Uji hipotesis dilakukan dengan koefisien determinasi (Nagelkerke $R$ Square), pengujian hipotesis secara simultan (Omnibust Test of Model Coefficient) dan pengujian hipotesis secara parsial (Uji Wald). Penelitian ini menggunakan program SPSS for Windows Version 23.00 dalam pengolahan data. 


\section{HASIL PENELITIAN DAN PEMBAHASAN}

H1: Current ratio (X1) memiliki nilai wald sebesar 0,259 dengan probabilitas signifikansi lebih besar dari alpha 0,05, yaitu 0,611, hal ini menunjukkan bahwa current ratio tidak terbukti berpengaruh secara signifikan terhadap Kualitas Audit.

H2: Total asset turnover ratio (X2) memiliki nilai wald sebesar 0,423 dengan probabilitas signifikansi lebih besar dari alpha 0,05, yaitu 0,516, hal ini menunjukkan bahwa total asset turnover ratio tidak terbukti berpengaruh secara signifikan terhadap Kualitas Audit.

H3: Debt-to equity ratio (X3) memiliki nilai wald sebesar 0,349 dengan probabilitas signifikansi lebih besar dari alpha 0,05 , yaitu 0,555 , hal ini menunjukkan bahwa debt-to equity ratio tidak terbukti berpengaruh secara signifikan terhadap Kualitas Audit.

H4: Return on assets (X4) memiliki nilai wald sebesar 1,231 dengan probabilitas signifikansi lebih besar dari alpha 0,05 , yaitu 0,267 , hal ini menunjukkan bahwa return on assets tidak terbukti berpengaruh secara signifikan terhadap Kualitas Audit.

H5: Price-to book value (X5) memiliki nilai wald sebesar 4,402 dengan probabilitas signifikansi lebih besar dari alpha 0,05, yaitu 0,036, hal ini menunjukkan bahwa price-to book value terbukti berpengaruh secara signifikan terhadap Kualitas Audit.

\section{PEMBAHASAN}

Interpretasi dari model kualitas audit dengan proksi KAP Big-4 dan non Big-4 yang pada penelitian ini bertujuan untuk memprediksi rasio keuangan yang diproksikan dengan current ratio, total asset turnover ratio, debt-to equity ratio, return on assets dan price-to book ratio dengan pendekatan regresi logistik telah memenuhi persyaratan spesifikasi model, hal ini diawali dengan uji multikolinearitas dan heteroskedastisitas, serta ditunjukkan dengan telah lolosnya hasil uji Hosmer and Lemeshow's Test dengan nilai chi-square sebesar 3,889 dan probabilitas signifikansi sebesar 0,867 (lebih besar dari alpha 5\%). Di samping itu, hasil uji koefisien determinasi $\left(\mathrm{R}^{2}\right)$ menghasilkan skor nagelkerke $R$ square yang agak rendah yaitu sebesar 0,151, sehingga hanya 15,1 persen variasi dari Kualitas Audit dijelaskan oleh variabel Rasio Keuangan. Sementara hasil uji omnibus tests of model coefficients menghasilkan nilai chi-square sebesar 8,433 dengan probabilitas signifikansi sebesar 0,134 (lebih besar dari alpha 5\%) sehingga uji hipotesis simultan tidak menunjukkan pengaruh yang signifikan. Di sisi lain, hanya satu faktor rasio keuangan yaitu rasio prospek pasar dengan proksi price-to book value (PBV) yang menunjukkan pengaruh secara individual yang dibuktikan melalui uji Wald dengan probabilitas signifikansi sebesar 0,036. 


\section{KESIMPULAN}

a. Berdasarkan hasil penelitian dan pembahasan, maka kesimpulan hasil penelitian yaitu: Uji model Kualitas Audit dalam memprediksi Rasio keuangan yang telah memenuhi persyaratan kelayakan model dengan pengujian Hosmer and Lemeshow's Test.

b. Uji model Kualitas Audit sebagai variasi atas Rasio keuangan hanya menghasilkan skor nagelkerke $\mathrm{R}$ square sebesar 0,151 yang berarti memiliki pengaruh yang lemah dalam menjelaskan model.

c. Uji model Kualitas Audit dalam memprediksi faktor Rasio Keuangan tidak menghasilkan pengaruh secara simultan dengan pengujian omnibus tests of model coefficients.

d. Uji model Kualitas Audit hanya menghasilkan 1 (satu) pembuktian hipotesis atas uji faktor Rasio Keuangan yang memiliki pengaruh signifikan secara parsial dengan uji Wald.

Berdasarkan hasil penelitian dan pembahasan, maka rekomendasi atau saran penelitian ini yaitu:

1. Pengukuran kualitas audit dapat dievaluasi tidak hanya berdasarkan proksi KAP Big-4 dan non Big-4 melainkan dapat dirumuskan kembali menggunakan proksi-proksi lainnya seperti honorarium, tenur audit, pergantian auditor, akrual diskresioner, jumlah anak perusahaan, penyajian kembali, opini going-concern, dan lainnya.

2. Penambahan periode penelitian dan subjek penelitian dapat dikembangkan pada penelitian mendatang tidak hanya terbatas pada kurun waktu 1 (satu) tahun melainkan periode yang lebih panjang serta objek penelitian pada perusahaan-perusahaan yang terdaftar di Bursa Efek Indonesia (BEI) dapat dipilih dengan kategori tertentu misalnya LQ-45, perusahaan sektor industri manufaktur, dan lainnya.

3. Penambahan faktor-faktor lainnya untuk menguji model kualitas audit seperti kondisi ekonomi, good corporate governance, pengungkapan CSR serta pengukuran rasio keuangan lainnya. 


\section{DAFTAR PUSTAKA}

Ball, R. (2009). Market and Political/Regulatory Perspectives on the Recent Accounting Scandals. Journal of Accounting Research, 47(2), 277-323.

Behn, B. K., Choi, J.-H., \& Kang, T. (2008). Audit Quality and Properties of Analyst Earnings Forecasts. The Accounting Review, 83(2), 327-349.

Brigham, E. F., \& Houston, J. F. (2016). Fundamentals of Financial Management (14 ed.). (J. Sabation, Ed.) Boston: Cengage Learning.

Carcello, J. V., Hollingsworth, C., \& Mastrolia, S. A. (2011). The effect of PCAOB inspections on Big 4 audit quality. Research in Accounting Regulation, 2 (2), 85-96.

Che, L., Hope, O.-K., \& Langli, J. C. (2019). How Big-4 Firms Improve Audit Quality. 1-54. DeAngelo, L. (1981b). Auditor Size and Audit Quality. Journal of Accounting and Economics, 3(3), 183-199.

DeFond, \& Zhang, J. (2014). A review of archival auditing research. Journal of Accounting and Economics, 58(2-3), 275-326.

DeFond, M. L., \& Francis, J. R. (2005). Audit Research after Sarbanes-Oxley. Auditing: A Journal of Practice \& Theory, 24 (Supplement 2005), 5-30.

DeFond, M., \& Jiambavlo, J. (1993). Factors Related to Auditor-Client Disagreements over Income-Increasing Accounting Methods. Contemporary Accounting Research, 9(Spring), 415-431.

DeFond, M., Erkens, D., \& Zhang, J. (2013). Do Client Characteristics Really Drive the Big N Effect? Evidence from Matching Methods.

Donovan, J., Frankel, R., Lee, J., Martin, X., \& Seo, H. (2014). Issues Raised by Studying DeFond and Zhang: What should Audit Researchers do? Journal of Accounting and Economics, 58, 327-338.

Ghanbari, M., Rashidi, A., \& Abbasi, N. (2018). A study of the effects of agency costs and information asymmetry on audit quality. Journal of Advanced Pharmacy Education \& Research, 8(Oct-Dec), 137-142.

Ghozali, I. (2017). Aplikasi Analisis Multivariate Dengan Program: IBM SPSS 23 (VIII ed.). Semarang: Badan Penerbit UNDIP.

Hassan, K., Khaldoon, A., \& Zhang, J. P. (2015). Is audit quality Implied by Accruals Quality associated with Audit fees and Auditor Tenure? Evidence from China. ICBEFM 2015 : International Conference on Business, Economics, Finance, and Management (July 13-14, 2015). 9. Stockholm, Sweden: World Academy of Science, Engineering and Technology.

Holmlund, M. (2008). A Definition, Model, and Empirical Analysis of Business-To-Business. International Journal of Service Industry and Management, 19(1), 32- 62.

Husain, T. (2019). An Analysis of Modeling Audit Quality Measurement Based on Decision Support Systems (DSS). European Journal of Scientific Exploration, 2(6), 1-9.

Husain, T. (2020). Mapping Evolution of Audit Quality Measurement. European Journal of Business and Management Research, 5(3), 1-7.

IIASB. (2014). A Framework for Audit Quality: Key Elements that Create an Environment for Audit Quality. New York: The International Federation of Accountants (IFAC). 
Indonesia Stock Exchange (IDX). (2015). Panduan IPO (Go Public). Jakarta: Bursa Efek Indonesia.

Martin, R. D. (2013). Audit Quality Indicators: Audit Practice Meets Audit Research. Current Issues in Auditing, 7(2), A17-A23.

Mashaekhi, B., Mehrani, K., Rahmani, A., \& Madahi. (2013). Development of audit quality model. Quarterly Journal of The Iranian Accounting and Auditing Review, 6(23), 103-137. 